\title{
Life quality and living standards in big cities under conditions of high-rise construction development
}

\author{
Elena Avdeeva ${ }^{1, *}$ Tatiana Averina ${ }^{1}$, Larisa Kochetova ${ }^{2}$ \\ ${ }^{1}$ Voronezh State Technical University, Moscow Avenue, 14, Voronezh, 394026, Russia \\ ${ }^{2}$ Russian University of Justice (Central branch), 20-letya Oktyabrya 95, Voronezh, 394006, Russia
}

\begin{abstract}
Modern urbanization processes occurring on a global scale inevitably lead to an increase in population density in large cities. People assess the state of life quality and living standards of megalopolises under conditions of high-rise construction development ambiguously. Using SWOT analysis, the authors distinguished positive and negative aspects of high-rise construction, highlighted threats to its development and its opportunities. The article considers the model of development of the city's industry and infrastructure, which enables determining the optimal volume of production by sectors and branches of city economy in order to increase its innovative, production and economic potential and business activity.
\end{abstract}

\section{Introduction}

Due to the increase in the number of people wishing to live in major centers of a country and the world, there is a sustainable tendency of forming megalopolises with a population of more than 1 million people and urban agglomerations that count more than 10 million people. This process began in the second half of the last century. In those years, the population of New York was more than 10 million people. In 1975, there were 5 cities of such size, in 2000 the number was 19, and according to the forecast 23 cities will overcome this line by 2025. The total number of high-rise buildings in the seven years has tripled. Leadership in the construction of skyscrapers belongs to Asia and the Middle East.

The top five global cities of GCI-2015 included New York, London, Paris, Tokyo and Hong Kong. Moscow was on the 14th place. As the evaluation criteria were used: political interaction, cultural and information exchange, human capital and economic activity.

According to Wikipedia, the megalopolis is the largest form of settlement, formed when a number of urban agglomerations merged. For the first time the term megalopolis appeared in 1915 in the book "Cities in Development" by the Scottish sociologist Patrick Geddes. Later, in 1938, American historian and philosopher of technology L. Mumford described the megalopolis as the first stage of urban overdevelopment and social decay. He made the conclusion about the initiating role of the subject in the placement of industry; considered hierarchical civilizations as megamachines and concluded that technology become an active subject of reality, transforming a person. In 1945 french geographer Jean Gottmann used this term to denote a continuous urban development with a length of more than $1000 \mathrm{~km}$

\footnotetext{
*Corresponding author: avdeeva ea@mail.ru
} 
and a width of up to $200 \mathrm{~km}$ along the Atlantic coast of the United States, which interconnected agglomerations of Boston, New York, Philadelphia, Baltimore, Washington. The population there amounted to 40 million people. He determined the mechanism of folding regions, states, civilizations as a natural interaction of close and related local "ways of life" .

The aim of this work is to study and evaluate the world trend of the formation of megalopolises and the rapid growth of high-rise construction, to analyze the impact of increasing the density of the population on the quality and standard of living in them. With the help of modeling the feasibility and economic attractiveness of the large city development was shown.

Large cities are leaders of regional and national development. Megalopolis is a weakly structured economic system with a large number of internal and external links. This economic and social system ensures the processes of current consumption, the reproduction of resources, the realization of future needs [1].

It attracts flows of labor resources and entrepreneurs, also being a large consumer market, where consumer and industrial goods and services are sold on a large scale. V. V. Ivanov believes that this is "the spatial structure of the post-industrial economy, the development mechanisms of which require special study. They are concentrated huge economic potential "[2].

\section{Materials and Methods}

For the analysis, statistical methods are used and SWOT analysis is applied. Any modern city is distinguished by the presence of high-rise buildings, characterizing it as highly developed, since this implies a high development of construction technologies, the availability of highly qualified specialists of architects, designers, developers, etc. Increasing the population density of large cities requires qualitatively new approaches to ensuring the safety of life and the use of new technologies as a factor of sustainable growth. The experience of European countries shows that the main increase in GDP is created in megacities [3]. These are the so-called "global cities" - a city that acts as the main driving force of progress in all areas of society, both in the scale of the national economy and the world system (Tables 1 and 2).

Table 1.10 countries with a high share of the world population, density of their people and GDP per head.

\begin{tabular}{|l|c|c|c|c|c|c|}
\hline № & Country & $\begin{array}{c}\text { Population, } \\
\text { people as of } \\
\mathbf{1 0 / 0 7 / 2 0 1 7}\end{array}$ & $\begin{array}{c}\text { Share of } \\
\text { world } \\
\text { population, } \\
\mathbf{\%} \text { as of } \\
\mathbf{1 0 . 0 7 . 2 0 1 7}\end{array}$ & $\begin{array}{c}\text { Density of } \\
\text { populatio } \\
\text { n, people } \\
\text { per km2, } \\
\text { as of } \\
\mathbf{1 0 . 0 7 . 2 0 1} \\
\mathbf{7}\end{array}$ & $\begin{array}{c}\text { Average } \\
\text { life } \\
\text { expectancy } \\
\text { years } \\
\text { according } \\
\text { to 2015) }\end{array}$ & $\begin{array}{c}\text { GDP } \\
\text { (nominal) } \\
\text { per capita, } \\
\mathbf{\$} \\
\text { (according } \\
\text { to IMF } \\
\text { data, 2016) }\end{array}$ \\
\hline 1 & China & 1384160000 & $18.4 \%$ & 648 & 76.1 & 8113 \\
\hline 2 & India & 1318270000 & $17.5 \%$ & 357 & 68.3 & 1723 \\
\hline 3 & USA & 325375000 & $4.33 \%$ & 32 & 79.3 & 57436 \\
\hline 4 & Indonesia & 261600000 & $3.48 \%$ & 127 & 69.1 & 3604 \\
\hline 5 & Brazil & 207709000 & $2.76 \%$ & 23.6 & 75 & 8727 \\
\hline 6 & Pakistan & 197750000 & $2.63 \%$ & 229 & 67.4 & 1468 \\
\hline 7 & Nigeria & 188500000 & $2.51 \%$ & 165 & 54.5 & 2211 \\
\hline 8 & Bangladesh & 162752000 & $2.17 \%$ & 1154 & 71.8 & 1411 \\
\hline 9 & Russia & 146400000 & $1.95 \%$ & 8.56 & 70.5 & 8928 \\
\hline 10 & Mexico & 129100000 & $1.69 \%$ & 57 & 76.7 & 8555 \\
\hline
\end{tabular}


About 4.3 billion people or about $58 \%$ of the world's population live in these ten countries.

Table 2. The largest cities in the world in terms of population density (according to the data for August 2016).

\begin{tabular}{|l|l|c|c|c|c|}
\hline № & $\begin{array}{c}\text { Cities with high- } \\
\text { rise } \\
\text { buildings }\end{array}$ & Population & $\begin{array}{c}\text { Total area } \\
\mathbf{( k m}^{\mathbf{2}}\end{array}$ & $\begin{array}{c}\text { Population } \\
\text { density } \\
\left(\mathbf{p e o p l e} / \mathbf{k m}^{\mathbf{2}}\right)\end{array}$ & Country \\
\hline 1 & Shanghai & 24256800 & 6340.50 & 3826 & China \\
\hline 2 & Karachi & 23500000 & 3527.00 & 6663 & Pakistan \\
\hline 3 & Beijing & 21516000 & 16410.54 & 1311 & China \\
\hline 4 & Delhi & 16349831 & 1483.00 & 11025 & India \\
\hline 5 & Lagos & 16060303 & 1171.28 & 13712 & Nigeria \\
\hline 6 & Tianjin & 15200000 & 11760.00 & 1293 & China \\
\hline 7 & Istanbul & 14160467 & 5461.00 & 2593 & Turkey \\
\hline 8 & Tokyo & 13513734 & 2191.00 & 6168 & Japan \\
\hline 9 & Guangzhou & 13080500 & 7434.40 & 1759 & China \\
\hline 10 & Mumbai & 12442373 & 603.40 & 20620 & India \\
\hline 11 & Moscow & 12197596 & 2510.12 & 4859 & Russia \\
\hline 12 & São Paulo & 11895893 & 1521.11 & 7821 & Brazil \\
\hline 13 & Shenzhen & 10467400 & 1991.64 & 5256 & China \\
\hline
\end{tabular}

Shanghai is the largest and most highly developed city in mainland China. The population density is almost 6 times higher than the average for China. The average life expectancy is also greater: in 2017 it is 83.37 years . GDP per head in 2016 was \$ 17548 . This is 2.2 times more than China's GDP per head. 2.74\% of residents age 15 and older were illiterate in 2010.

Karachi is the main economic center and seaport of Pakistan. The density of the city's population is 29 times higher than the density in the country. A similar situation is observed in Delhi: the population density is 31 times higher than the population of India.

The total population density of Russia was 8.56 people $/ \mathrm{km}^{2}$ as of January 1, 2017.

The population is disposed extremely unevenly: $68.3 \%$ of Russians live in the European part of Russia, which comprises $20.82 \%$ of the territory. The density of the population of European Russia is 27 people $/ \mathrm{km}^{2}$, when the population of Asian part of the country is 3 people $/ \mathrm{km}^{2}$. The urban population is $74.27 \%$ (2017). Moscow is the leading city by the number and density of the population counting 4834.31 people $/ \mathrm{km}^{2}$.

Moscow is the only city of Russia, which is considered a megalopolis with high-rise buildings. The tallest building in Moscow is the "Tower of Moscow", which is part of the "City of Capitals" complex. The height of the Moscow skyscraper built in 2009 is 301 meters. In the 76-storey building there are residential apartments, as well as a business center. Currently, the "Tower of Moscow" has become the tallest building in Europe and the CIS countries. In Moscow, there are 4.5 thousand buildings and structures with a height of more than $50 \mathrm{~m}$. Moscow leads in all indicators of socio-economic development. Per head income in 2016 was 59567.0 rubles per month, and in the Moscow region - 38395.9 rubles per month, which is significantly higher than the average for Russia - 30448.1 rubles per month. In absolute terms, the GRP of Moscow in 2016 amounted to 13.9194 trillion rubles.

The success of the development of large cities is one of the factors in the transition to an innovative economy and the competitiveness of the Russian economy. The problem of 
providing citizens with comfortable, affordable housing is still relevant. There is a structural housing deficit in the country, $75-80 \%$ of housing stock is equipped with basic communal services, the proportion of dilapidated and emergency housing is sufficiently high. For many cities in Russia, high-rise buildings will help solve the above problems. A number of cities began to implement programs of high-rise construction, for instance Novosibirsk and Yekaterinburg [4, 5].

\section{Results}

The conducted analysis of the strengths and weaknesses of high-rise buildings is presented in Table 3.

Table 3. SWOT matrix of high-rise development analysis

\begin{tabular}{|c|c|}
\hline Strengths & Weaknesses \\
\hline $\begin{array}{l}\text { The political weight, determined by the number of } \\
\text { projects in the field of international cooperation, the } \\
\text { number of foreign embassies and international missions } \\
\text { Saving of land } \\
\text { High level of business activity } \\
\text { Innovative scientific and educational potential } \\
\text { National and world scale of commodity and stock } \\
\text { markets } \\
\text { Concentration of large financial structures } \\
\text { The presence of a large number of well-paid jobs } \\
\text { Active information exchange through the media of global } \\
\text { importance } \\
\text { Highly developed information and communication } \\
\text { infrastructure } \\
\text { High cultural level availability of a large number of } \\
\text { theaters, museums, concert and exhibition halls of the } \\
\text { world level, large flows of foreign tourists } \\
\text { The level and quality of life is much higher than other } \\
\text { territories, the presence of social infrastructure }\end{array}$ & $\begin{array}{l}\text { High concentration of population } \\
\text { Limited area } \\
\text { Very high environmental load } \\
\text { Expensive home exploitation } \\
\text { Lack of own natural resources } \\
\text { High environmental load, huge waste } \\
\text { streams and emissions of road } \\
\text { transport }\end{array}$ \\
\hline Opportunities & Threats \\
\hline $\begin{array}{l}\text { Dispelling fears of people about life in high-rise } \\
\text { buildings } \\
\text { Reducing the cost of operation (after } 20 \text { floors each next } \\
3 \text { floors add an additional } 10 \% \text { to the } 150 \% \text { of the cost of } \\
\text { exploitation, which already exists). } \\
\text { Demonstration of uniqueness (view from windows, } \\
\text { infrastructure in the house and possible work place) } \\
\text { Possibility of development in the city center } \\
\text { The use of vertical landscaping of buildings as a means of } \\
\text { decoration } \\
\text { Safety of elevators - the use of water poles supporting } \\
\text { special metal structures floating in evacuation mines, } \\
\text { their carrying capacity is up to thousand people } \\
\text { Equipping a helicopter landing site in case of evacuation } \\
\text { of people } \\
\text { Using BIM technologis }\end{array}$ & $\begin{array}{l}\text { The complex residential structure, } \\
\text { attracting an unfavorable social } \\
\text { climate, vandalism, crime } \\
\text { Risks related to quality, safety - } \\
\text { seismic hazard, strong wind, draft } \\
\text { high cost of high-rise housing } \\
\text { propaganda of low-rise buildings }\end{array}$ \\
\hline
\end{tabular}




\section{Discussions}

Even by the number of positions in each column, one can talk about the expediency and prospects of high-rise buildings of large cities. This can be justified by statistical data. The Human Development Index (HDI) in 2014 was 0.946 in Moscow, compared with 0.874 for Russia as a whole. This is a high factor, which is comparable to Poland, the Czech Republic, and the Baltic countries. It takes into account the expected life expectancy, duration of citizenship education and national income per capita. Among the countries of the world, Russia ranks 55th [6,7]. Therefore, it is important for Russia to promote the development of large cities.

In order to determine the directions of the megacity development, it is necessary to allocate the following groups of territories: industrial, agricultural, special purpose, engineering infrastructure, transport infrastructure, public-business, recreational, natural, water areas. Investing in any of these areas involves getting as much income as possible on invested capital. Not only investors and enterprises are interested in this, but budgets of all levels need them. Expansion of investments in the economy of a particular city increases its production and economic potential and business activity. There is an increase in the employment of the population, an increase in the collection of taxes, the social sphere is supported. The main indicator of efficiency in the long run is net discounted income, the guarantee yield index. As Marshall wrote, "the time factor underlies the main difficulties in solving almost any economic problem." The development of the program for the development of the functioning of the industrial-infrastructural complex is carried out using modeling based on the model of V.V. Glukhova and M.E. Oseevsky.

The task is to determine by years the planned period of capacity, output by sector of the economy and infrastructure sectors. It is necessary to take into account own consumption in the branches, inter-branch relations, external deliveries, attracted number of employees [8].

Introduce the unknown planned values of $\mathrm{x}$ and $\mathrm{y}$, then the volume of production is determined by the need of the city's economy:

$$
\mathrm{y}_{\mathrm{n}}(\mathrm{t})=\mathrm{y}_{\mathrm{n}}{ }^{0}(\mathrm{t})+\mathrm{y}_{\mathrm{n}}{ }^{1}(\mathrm{t})+\sum_{\mathrm{m}} \mathrm{a}_{\mathrm{mn}}(\mathrm{t}) \mathrm{x}_{\mathrm{mn}}(\mathrm{t})
$$

where $\mathrm{x}_{\mathrm{mn}}(\mathrm{t})$ is a product consumption of $\mathrm{n}$ th industry in $\mathrm{m}$-th industrial sector in a year $\mathrm{t}$

$a_{m n}(t)$ is a specific consumption of products of $n-t h$ service industry in $m$-th industrial sector in a year $t$

$y_{n}{ }^{0}(t)$ - internal consumption of the product of $n-t h$ industrial sector in a year $t$

$y_{n}{ }^{1}(t)$ - other consumption of the product of $n$-th service industry transfer out of the

territory of a megalopolis, consumption in the housing and communal services, in the nonproduction sphere in the year $\mathrm{t}$.

Capabilities of infrastructure are limited by its capacities:

$$
\mathrm{y}_{\mathrm{n}}{ }^{\max }(\mathrm{t}) \geq \mathrm{y}_{\mathrm{n}}(\mathrm{t})
$$

where $y_{n}{ }^{\max }(t)$ - capacity of $\mathrm{n}$-th service industry

$\mathrm{y}_{\mathrm{n}}(\mathrm{t})$ - determined product demand of $\mathrm{n}$-th industry in a year $\mathrm{t}$.

The possible volume of production of the industrial complex is determined by external need and internal cooperation:

$$
\mathrm{x}_{\mathrm{m}}(\mathrm{t})=\mathrm{x}_{\mathrm{m}}{ }^{0}(\mathrm{t})+\sum_{\mathrm{n}} \mathrm{x}_{\mathrm{mn}}(\mathrm{t})+\sum_{\mathrm{m}} \sum_{1} \mathrm{z}_{\mathrm{m} 1}(\mathrm{t})
$$

Where $\mathrm{x}_{\mathrm{m}}{ }^{0}(\mathrm{t})$ - own consumption in $\mathrm{m}$-th industrial sector in a year $\mathrm{t}$

$\mathrm{x}_{\mathrm{mn}}(\mathrm{t})$ - consumption of industrial sector products in $\mathrm{n}$-th service industry in a year $\mathrm{t}$ 
$\mathrm{z}_{\mathrm{m} 1}$ - product consumption of $\mathrm{m}$-th industrial sector in the first sector of industry in a year $\mathrm{t}$.

Capabilities of industry sectors are limited by their capacity

$$
\mathrm{x}_{\mathrm{m}}{ }^{\max }(\mathrm{t}) \geq \mathrm{x}_{\mathrm{m}}(\mathrm{t})
$$

where $x_{m}{ }^{\max }(t)$ - capacity of $m$-th industrial sector $x_{m}(t)$ - planned consumption in $\mathrm{m}$-th industrial sector in a year $t$. The number of workers is one of the limiting resources, which is described by the conditions:

$$
\begin{gathered}
\mathrm{N}_{\mathrm{n}}(\mathrm{t})=\mathrm{b}_{\mathrm{n}} \mathrm{y}_{\mathrm{n}}(\mathrm{t}), \\
\mathrm{N}_{\mathrm{m}}(\mathrm{t})=\mathrm{b}_{\mathrm{m}} \mathrm{y}_{\mathrm{m}}(\mathrm{t}), \\
\mathrm{N}(\mathrm{t})=\mathrm{N}_{\mathrm{n}}(\mathrm{t})+\mathrm{N}_{\mathrm{m}}(\mathrm{t}), \\
\mathrm{N}^{\max }(\mathrm{t}) \geq \mathrm{N}(\mathrm{t}),
\end{gathered}
$$

where $\mathrm{N}(\mathrm{t})$ - total demand in employees

$\mathrm{N}_{\mathrm{m}}(\mathrm{t})$ - demand in workers of $\mathrm{m}$-th industrial sector

$b_{m}$ - need for workers per unit of output in $m$-th industrial sector

$\mathrm{N}_{\mathrm{n}}(\mathrm{t})$ - need for workers in $\mathrm{n}$-th service industry

$b_{n}$ - need for workers per unit of output in $n$ - th service industry

$\mathrm{N}^{\max }(\mathrm{t})$ - the maximum permissible labor resource.

Wages of workers depend on the expected average payments:

$$
\mathrm{W}(t)=\sum c_{n}(t) N_{n}(t)+\sum c_{m}(t) N_{m}(t)
$$

where $\mathrm{W}(t)$ is total wage

$c_{n}(t)$ и $c_{m}(t)$ - average wages in $m$-th industrial sector and $n$-th service industry respectively.

The form of production process and the degree of availability of products depends on the volume of materials, components and tools delivered:

$$
\mathrm{B}_{\mathrm{s}}=\sum_{\mathrm{n}} \mathrm{b}_{\mathrm{sn}} \mathrm{y}_{\mathrm{sn}}+\sum_{\mathrm{m}} \mathrm{b}_{\mathrm{sm}} \mathrm{x}_{\mathrm{m}}
$$

where $B_{s}$ - the total amount of incoming materials by $S$-th flow entering the city, $b_{s n}$ and $\mathrm{b}_{\mathrm{sm}}$ - specific demand for materials in $\mathrm{m}$-th sector of industry and $\mathrm{n}$-th service industry, received by $\mathrm{s}$-th flow entering the city

Material flows determine the capacity of transport highways:

$$
\mathrm{B}_{\mathrm{s}}{ }^{\max } \geq \mathrm{B}_{\mathrm{s}}
$$

where $\mathrm{B}_{\mathrm{s}}{ }^{\max }$ - maximum capacity of $\mathrm{s}$-th flow entering the city

$\mathrm{B}_{\mathrm{s}}$ - total planned amount of incoming materials by $\mathrm{s}$-th flow entering the city

Tax revenues to the city budget are determined by the normative base adopted in the city, tax benefits granted by enterprises, production volumes:

$$
\mathrm{F}_{\mathrm{k}}(\mathrm{t})=\sum_{\mathrm{m}} \mathrm{f}_{\mathrm{km}}(\mathrm{t}) \mathrm{x}_{\mathrm{m}}(\mathrm{t})+\sum_{\mathrm{n}} \mathrm{f}_{\mathrm{kn}}(\mathrm{t}) \mathrm{y}_{\mathrm{n}}(\mathrm{t})
$$

where $F_{k}(t)$ - amount of $k$-th form of tax revenue to the city budget

$\mathrm{f}_{\mathrm{km}}$ and $\mathrm{f}_{\mathrm{kn}}$ - specific amount of taxation of $\mathrm{k}$-th form of $\mathrm{m}$-th product in industrial sector and of $\mathrm{n}$-th product of service industry.

The integral indicator, the minimum of which must be ensured, is the sum of deviations from the desired amount of tax revenues to the budget. In this case, deviations are taken into account only in the form of a shortfall of the income amount 


$$
\min \mathrm{J}_{1}=\min \sum_{\mathrm{t}} \mathrm{g}_{\mathrm{t}} \sum_{\mathrm{k}} \mathrm{e}_{\mathrm{k}} \mathrm{F}_{\mathrm{k}}(\mathrm{t})
$$

Maximum amount of tax revenues to the budget can be an alternative indicator:

$$
\max \mathrm{J}_{2}=\max \sum_{\mathrm{t}} \mathrm{g}_{\mathrm{t}} \sum_{\mathrm{k}} \mathrm{e}_{\mathrm{k}} \mathrm{F}_{\mathrm{k}}(\mathrm{t})
$$

where $F_{k}{ }^{0}(t)$ - desired tax revenue path of $k$-th form to the city budget $F_{k}(t)$ - amount of $k$-th form of tax revenues to the city budget in a year $t$ $\mathrm{e}_{\mathrm{k}}$ - validity of $\mathrm{k}$-th form of tax for the budget $\mathrm{g}_{\mathrm{t}}$ - validity of $\mathrm{t}$-th year for the total planned period.

Thus, when elaborating development scenarios, it is necessary to focus on the development of capacities, production volumes, the supply of labor resources, and the capacity of the infrastructure sectors. The application of this model is possible to megalopolises and urban agglomerations.

\section{Conclusion}

The regions of Russia are distinguished by a strong heterogeneity in socio-economic development, different natural and resource potential, climatic conditions, transport infrastructures, etc. If the control arms are concentrated in a certain region, it allows attracting financial resources, highly skilled specialists, implementing innovative projects in a number of industries, financing budgetary areas. All listed above enhances the quality and standard of living of the governor's region, as well as the manufacturing regions, as investment flows are directed into industrial production.

\section{References}

1. A. Larionov, E. Nezhnikova, International Journal of Applied Engineering Research, 6, 4433-4439 (2016)

2. E. Nezhnikova, IOP Conf. Series: Earth and Environmental Science, 90, 012161 (2017) doi:10.1088/1755-1315/90/1/012161

3. V. Kankhva, IOP Conf. Series: Earth and Environmental Science, 90, 012175 (2017) doi:10.1088/1755-1315/90/1/012175

4. V.V. Ivanov, Nauka (2015)

5. S.A. Kolesnikov, Vestnik MGSU, 1, 7-15 (2015)

6. E.A. Avdeeva, T.E. Davydova, Ekonomika i predprinimatel'stvo, 10-1 (2017)

7. T.A. Averina, Sistemy upravleniya i informacionnye tekhnologii, 45 (2011)

8. I.V. Ilin, A.B. Anisiforov, WSEAS Transactions on Business and Economics, 11, 757764 (2014) 